\title{
A Case of Stuttering Due to Olanzapine Treatment
}

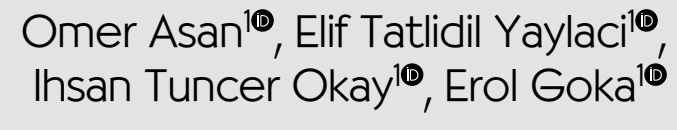

'Ankara Numune Training and Research Hospital, Department of Psychiatry, Ankara - Turkey

\section{ABSTRACT}

A case of stuttering due to olanzapine treatment

Stuttering is defined as a disturbance in time patterning and fluency of speech inappropriate for an individual's age. The pathophysiology of stuttering is not fully understood. Some studies show that stuttering is related with an increased number of D2 receptors in the basal ganglia. Otherwise, a $50-200 \%$ increase in the level of dopaminergic activity has been found in stuttering cases in comparison to the control group. Stuttering as a side-effect of psychotropic medication is rare. Only a few stuttering cases are reported in the literature as being due to effects of antipsychotics like chlorpromazine, clozapine, olanzapine, risperidone, or trifluoperazine. Olanzapine is also used to treat the symptoms of stuttering via D2 receptor antagonism, and in the literature there are cases treated with the administration of olanzapine. Here we present a case of olanzapine-induced stuttering. The importance of this case is to show that while olanzapine may be used in the treatment of stuttering, it may also be the cause of stuttering as an adverse effect.

Keywords: Drug side effects, olanzapine, stuttering

\section{öz}

Olanzapin kullanımına bağlı gelişen bir kekemelik olgusu

Kekemelik; yaşla uyumsuz olarak konuşmanın akıcılığı ve zamanlamasındaki bozukluk olarak tanımlanır. Etiyolojisi halen tam olarakbilinmemektedir. Yayınlanmış bazı çalışmalarkekemeliğin bazal gangliyonlarda artmış D2 reseptör seviyesiyle ilişkili olduğunu göstermiştir. Ayrıca kekemelik olgularında kontrol grubuna göre \%50-200 oranında artmış dopaminerjik aktivite saptanmıştır. Kekemelik nadiren psikotropik ilaçların yan etkisi olarak ortaya çıkmaktadır. Literatürde az sayıda klorpromazin, klozapin, olanzapin, risperidon ve trifluperazin kullanımına bağlı gelişmiş kekemelik olguları mevcuttur. Aynı zamanda olanzapinin D2 reseptör antagonizması yaparak kekemelik semptomlarını düzelttiğini belirten olgular da yayınlanmıştır. Bu olgu sunumunda olanzapin kullanımına bağlı gelişen bir kekemelik olgusu sunduk. Bu olgu olanzapinin kekemelik semptomlarının tedavisinde kullanılmasının yanı sıra, bir yan etki olarak kekemeliğe yol açabildiğini göstermesi açısından önemlidir.

Anahtar kelimeler: Yan etki, olanzapin, kekemelik

\begin{abstract}
How to cite this article: Asan O, Tatlidil-Yaylaci E, Okay IT, Goka E. A case of stuttering due to olanzapine treatment. Dusunen Adam The Journal of Psychiatry and Neurological Sciences 2018;31:405408.

https://doi.org/10.5350/DAJPN2018310410
\end{abstract}

Address reprint requests to / Yazışma adresi: Omer Asan,

Ankara Numune Training and Research

Hospital, Department of Psychiatry,

Ankara, Turkey

Phone / Telefon: +90-312-508-5604

E-mail address / Elektronik posta adresi: omerasan@hotmail.com

Date of receipt / Geliş tarihi: March 18, 2017 / 18 Mart 2017

Date of the first revision letter /

ilk düzeltme öneri tarihi:

April 9, 2017 / 9 Nisan 2017

Date of acceptance / Kabul tarihi:

April 23, 2018 / 23 Nisan 2018

\section{INTRODUCTION}

S tuttering can be defined as a disturbance in the fluency and time patterning of speech inadequate for the speaker's age. Characteristics of stuttering are the repetition and prolongation of sounds and syllables, blocking or pauses between sounds or words, and in addition a strong feeling of anxiety accompanying the act of speaking $(1,2)$. Other actions that can go along with stuttering are grimacing, tremor, and blinking $(3,4)$. There are 2 subtypes of stuttering: developmental and acquired, respectively. The most commonly form is developmental, generally setting on between the ages of 2 and 7 years, and in $80 \%$ of cases, it resolves spontaneously (5). Acquired stuttering can start at any age, the most common causes being stroke, adverse drug effects, head trauma, brain tumors, and problems related to the central nervous system. For stuttering, a prevalence of around $1 \%$ in the general population has been reported (5). The lifetime probability for a person to develop stuttering is $3-4 \%(6,7)$. The condition is seen in males 3-4 times more frequently than in females $(8,9)$. One of the first neurophysiological models trying to explain the cause of stuttering is the theory of cerebral dominance. This theory assumes that the lateralization of speech in the brain is atypical, being represented in both hemispheres, thereby affecting the fluidity of speech. According to this model, inappropriate lateralization causes a disturbance in the 
synchronization of the motor stimuli directed to the speech muscles and a wrong timing of the muscle movements, which leads to a disruption of fluid speech (10). Developments in electrophysiological and brain imaging technologies have provided important insights into stuttering. Electroencephalogram (EEG) studies have reported atypical stimulation patterns such as a suppression of alpha waves. PET and SPECT studies found a general increase in the activation of the cortical and subcortical areas. Functional MRE studies reported an increased right-hemisphere activity during speech. Another important model to account for the etiology of stuttering is the dopamine hypothesis. According to this model, stuttering is related with an abnormal increase in the cerebral dopaminergic activity. PET imaging studies have also demonstrated that the dopaminergic activity in stutterers was 50-200\% higher than in controls (11). PET studies also found reduced striatal metabolism in stutterers. In this model, given that dopamine is a striatal metabolism inhibitor, the increase of dopaminergic activity inhibits the striatal metabolism and can cause stuttering (12). Studies showing that dopaminergic activity-enhancing agents, such as levodopa, increase symptoms of stuttering support the dopamine hypothesis (13). Clinical studies show that dopamine antagonists are effective in the treatment of stuttering. Haloperidol, tiapride, risperidone, and olanzapine have been found superior to placebo in improving the symptoms of stuttering (14-17). A number of agents have been tried in the treatment of stuttering, but none of them has been licensed by the U.S. Food and Drug Administration (FDA) so far. Studies indicate that the most promising drugs are antidopaminergic agents such as haloperidol, risperidone, and olanzapine. According to the dopaminergic hypothesis, these agents correct the striatal metabolism by suppressing the increased dopaminergic activity and thus improve the symptoms of stuttering. Some studies showed that calcium channel blockers such as verapamil may also achieve a partial improvement in stuttering therapy $(18,19)$. Clinical studies with other agents found benzodiazepines and antihistaminics not to be effective in stuttering therapy (20-22). In one case, treatment with fluoxetine (a selective serotonin reuptake inhibitor, SSRI) was successful (23).

\section{CASE}

A 21-year-old male person presented to the psychiatric policlinic of our hospital with complaints of increased psychomotor activity, aggressive behavior, and fast and pressured speech. In the mental state examination, the patient's cooperation was limited, his words were partial answers to the questions, his speech was fast and pressured, his associations disorganized. The content of his thoughts showed delusions of reference and persecution, his psychomotor activity was increased. Because of psychomotor agitation, the emergency department had given an injection of $10 \mathrm{mg}$ haloperidol and $5 \mathrm{mg}$ biperiden IM and then referred the patient to our inpatient service for differential diagnosis and treatment planning. CBC, AST, ALT, urea, creatine, electrolyte panel, infection panel, and endocrine tests, EEG and brain MRI investigation carried out immediately after admission to our ward showed no pathologies. The patient was started on a dose of $10 \mathrm{mg} /$ day olanzapine with a preliminary diagnosis of psychotic disorder. On the third day of treatment, stuttering symptoms such as disturbance in the fluency and time patterning of speech, repetition of sounds and syllables, blocking between words, and accompanying strong signs of anxiety began. Anamnesis received from the patient and his relatives did not indicate any past episodes of stuttering. Examination and follow-up of the patient did not find any other extrapyramidal system (EPS) side effects or akathisia. Neurological assessment and EEG carried out in the neurology department did not find any pathology to explain the stuttering. As the stuttering symptoms increased and no other etiology was found, olanzapine treatment was stopped on the sixth day and a therapy with $200 \mathrm{mg} /$ day quetiapine was started. After discontinuing olanzapine, stuttering symptoms quickly improved, and on the third day the patient's speech returned to normal. 


\section{DISCUSSION}

The most important hypothesis to explain the etiology of stuttering is the inhibition of the striatal metabolism caused by an increase in dopaminergic activity. This hypothesis is also supported by the fact that antipsychotic agents with dopamine-antagonist action like haloperidol, risperidone, or olanzapine are effective in the treatment of stuttering. However, the case we are presenting paradoxically shows that olanzapine, contrary to the hypothesis, is the cause of stuttering and its discontinuation results in a quick improvement of the symptoms. A literature search shows that a small number of cases have been published where stuttering occurred as a side effect of antipsychotic drugs. Thus, 3 cases reported the development of stuttering related to the use of risperidone $(24,25)$. A case series described 7 incidents where stuttering was related to a drug side effect, 6 of which were olanzapine-related and 1 case linked to the use of clozapine (26). This series involved concomitant use of antidepressants and previous head trauma, which reportedly may have increased the risk of this side effect.

Another significant issue with drug-related speech disturbances concerns EPS side effects. Especially speech impediment occurring with pharyngeal dystonia and involvement of the buccolingual muscles or anxiety related to the side effect of akathisia alongside lisping speech are frequently encountered. Some publications report that the side effect of stuttering is found together with EPS side effects or that EPS side effects may even be related with a clinical presentation or with epileptic activity $(27,28)$. Though to a lesser degree than first generation antipsychotics, olanzapine may cause D2 receptor antagonism-related EPS side effects and akathisia as well as lower the threshold of epilepsy (29). What distinguishes our case from other possible adverse effects is that no EPS side effects occurred, EEG and neurological examination found no pathology, signs of anxiety only arose together with speech impediment, and in addition to disturbances in fluency and time patterning of speech, characteristic symptoms of stuttering such as repetition of sounds and syllables, prolongation, and blocking or hesitation between sounds or words were present.

Our case and others found in the literature demonstrate that stuttering can occur as a rare adverse effect of antipsychotics. It is worth noting that olanzapine, in addition to being used in the treatment of stuttering, may itself cause stuttering as a side effect. While atypical and typical antipsychotics suppress increased dopaminergic activity, atypical antipsychotics such as olanzapine paradoxically may also increase dopaminergic activity via the 5-HT2A receptor. Our case demonstrates that olanzapine, frequently used in the treatment of stuttering, may rarely give rise to stuttering as a side effect, and it is important for clinicians to keep this side effect in mind.

\begin{tabular}{|l|l|l|}
\hline \multicolumn{2}{|l|}{ Contribution Categories } & Author Initials \\
\hline \multirow{4}{*}{ Category 1} & Concept/Design & O.A., E.T.Y, I.T.O. \\
\cline { 2 - 3 } & Literature review & O.A., E.T.Y, E.G. \\
\cline { 2 - 3 } & Data analysis/Interpretation & O.A., E.T.Y, I.T.O. \\
\cline { 2 - 3 } & Case follow-up (if applicable) & O.A., E.T.Y, E.G. \\
\hline \multirow{3}{*}{ Category 2} & Drafting manuscript & O.A., E.T.Y \\
\cline { 2 - 3 } & Critical revision of manuscript & O.A., E.T.Y, I.T.O., E.G. \\
\hline Category 3 & Final approval and accountability & O.A., E.T.Y, I.T.O., E.G. \\
\hline \multirow{3}{*}{ Other } & Technical or material support & N/A \\
\cline { 2 - 3 } & Supervision & E.G. \\
\cline { 2 - 3 } & Securing funding (if applicable) & N/A \\
\hline
\end{tabular}

Informed Consent: Written consent was obtained from the participants.

Peer-review: Externally peer-reviewed.

Conflict of Interest: Authors declared no conflict of interest.

Financial Disclosure: Authors declared no financial support. 


\section{REFERENCES}

1. Maguire GA, Yeh CY, Ito BS. Overview of the diagnosis and treatment of stuttering. J Exp Clin Med 2012; 4:92-97. [CrossRef]

2. American Psychiatric Association. Diagnostic and Statistical Manual of Mental Disorders Fourth Ed., Text Revision. Washington, DC; 2000.

3. Guitar BE. Stuttering and stammering. Pediatr Rev 1985; 7:163168. [CrossRef]

4. Maguire G. Without Hesitation: Speaking to the Silence and the Science of Stuttering. New York, NY: National Stuttering Association, 2010.

5. Andrews G, Craig A, Feyer A, Hoddinott S, Howie P, Neilson M. Stuttering: a review of research findings and theories circa 1982. J Speech Hear Disord 1983; 48:226-246. [CrossRef]

6. Aras S. Communication Disorders: In Gulec C, Koroglu E (editors). Foundations of Psychiatry. Second ed., Ankara: Physicians' Publishing Union, 2007, 777-797. (Turkish)

7. Ashurst JV, Wasson MN. Developmental and persistent developmental stuttering: an overview for primary care physicians. J Am Osteopath Assoc 2011; 111:576-580.

8. Belgin E, Derinsu U. Incidence of speech and voice disorders in primary school children. 19. National Turkish Congress of Otorhinolaryngology. Istanbul, 1990, 158-160. (Turkish)

9. Bloodstein O. A Handbook on Stuttering, Fifth Ed., San Diego: Singular Publishing Group, 1995.

10. Blood GW. Laterality differences in child stutterers: heterogeneity, severity levels, and statistical treatments. J Speech Hear Disord 1985; 50:66-72. [CrossRef]

11. Wu JC, Maguire G, Riley G, Lee A, Keator D, Tang C, Fallon J, Najafi A. Increased dopamine activity associated with stuttering. Neuroreport 1997; 8:767-770. [CrossRef]

12. Wu JC, Maguire G, Riley G, Fallon J, LaCasse L, Chin S, Klein E, Tang C, Cadwell S, Lottenberg S. A positron emission tomography [18F] deoxyglucose study of developmental stuttering. Neuroreport 1995; 6:501-505. [CrossRef]

13. Anderson JM, Hughes JD, Rothi LJ, Crucian GP, Heilman KM. Developmental stuttering and Parkinson's disease: the effects of levodopa treatment. J Neurol Neurosurg Psychiatry 1999; 66:776-778. [CrossRef]

14. Rosenberger PB, Wheelden JA, Kalotkin M. The effect of haloperidol on stuttering. Am J Psychiatry 1976; 133:331-334.

\section{[CrossRef]}

15. Rothenberger A, Johannsen HS, Schulze H, Amorosa H, Rommel D. Use of tiapride on stuttering in children and adolescents. Percept Mot Skills 1994; 79:1163-1170.

16. Maguire G, Riley GD, Franklin DL, Gottschalk LA. Risperidone for the treatment of stuttering. J Clin Psychopharmacol 2000; 20:479-482. [CrossRef]

17. Maguire GA, Riley G, Franklin DL, Maguire ME, Nguyen CT, Brojeni PH. Olanzapine in the treatment of developmental stuttering: a double-blind, placebo-controlled trial. Ann Clin Psychiatry 2004; 16:63-67. [CrossRef]

18. Brady JP, McAllister TW, Price TR. Verapamil in stuttering. Biol Psychiatry 1990; 27:680-681. [CrossRef]

19. Maguire G, Riley G, Hahn R, Plon L. Nimodipine in the treatment of stuttering. ASHA J 1994;36:51.

20. Brady JP. The pharmacology of stuttering: a critical review. Am J Psychiatry 1991; 148:1309-1316. [CrossRef]

21. Stager S, Calis K, Grothe D, Bloch M, Turcasso N, Ludlow C, Braun A. A double blind trial of pimozide and paroxetine for stuttering: In Hulstijn W, Peters HFM, Van Lieshout PHHM (editors). Speech Production: Motor Control, Brain Research and Fluency Disorders. Amsterdam: Elsevier, 1997, 379-382.

22. Yannatos G, L'hydroxyzine dans la therapeutique des begaiements. J Fr Otorhinolaryngol Chir Maxillofac 1960; 9:293-296.

23. Kumar A, Balan S. Fluoxetine for persistent developmental stuttering. Clin Neuropharmacol 2007; 30:58-59. [CrossRef]

24. Atay IM, Tanritanir B, Akpinar A, Demirdas A. A Case of Risperidone Induced Stuttering as a Paradox. Case Report. Noro Psikiyatr Ars 2014; 51:403-404. [CrossRef] (Turkish)

25. Yadav DS. Risperidone induced stuttering. Gen Hosp Psychiatry 2010; 32:559.e9-10. [CrossRef]

26. Bar KJ, Hager F, Sauer H. Olanzapine and clozapine induced stuttering. A case series. Pharmacopsychiatry 2004; 37:131-134. [CrossRef]

27. Thomas P, Lalaux N, Vaiva G, Goudemand M. Dose-dependent stuttering and dystonia in a patient taking clozapine. Am J Psychiatry 1994; 151:1096. [CrossRef]

28. Vossler DG, Haltiner AM, Schepp SK, Friel PA, Caylor LM, Morgan JD, Doherty MJ. Ictal stuttering: a sign suggestive of psychogenic nonepileptic seizures. Neurology 2004; 63:516-519. [CrossRef]

29. Gulec G, Rukiye YK. Seizure associated with olanzapine: case report. Bulletin of Clinical Psychopharmacology 2007; 17:134137. (Turkish) 